Scientific contribution/Original research

\title{
Samuel Gmelin (18th century): Inspiration from the Past through Science, Technology, Engineering, the Arts, and Mathematics Approach
}

Istileulova $Y^{*}$

* Correspondence: Yelena Istileulova yelena.istileulova@fulbrightmail.org

Citation: Istileulova Y. Samuel Gmelin (18th century): Inspiration from the past through science, technology, engineering, the arts, and mathematics approach. Proceedings of Socratic Lectures. 2021; 6: 190-193.

https://doi.org/10.55295/PSL.2021.D. 024

Publisher's Note: UL ZF stays neutral with regard to jurisdictional claims in published maps and institutional affiliations.

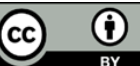

Copyright: (C) 2021 by the authors. Submitted for possible open access publication under the terms and conditions of the Creative Commons Attribution (CC BY) license (https://creativecommons.org/licenses/b $\mathrm{y} / 4.0 /)$.

\begin{abstract}
:
Samuel Gmelin, the German physician, explorer and botanist is known for two books, a "Historia Fucorum" in 1786, and "Travels through Russia to Investigate the Three Natural Realms" between 1770-1774. The new method of SMS (Stories based on Music about Scientists) is introduced under the umbrella of STEAM (Science, Technology, Engineering, the Arts, and Mathematics) approach inspiring an interest towards scientists of the Past and their innovations. The method is illustrated on the example of Samuel Gmelin's life and represents the new learning and teaching method.
\end{abstract}

Keywords: STEAM; 


\section{Introduction}

The discoveries and innovations are very often coming from the inspiration of stories and life of scientists of the Past perceived through a prism of the Present. The goal of this article is to demonstrate the new method SMS (Stories based on Music about Scientists) which can be applied under the STEAM approach on the example of inspiring life of Samuel Gmelin (1744, Tübingen, Germany - 1774, Dagestan (Derbent), Russia).

Samuel Gottlieb Gmelin, the German physician, explorer and botanist, was a member of celebrated family of German naturalists with Russian connections thanks to his uncle Johann Georg Gmelin (1709-1755) (Silva et al.,1996) Gmelin is known for two books, "Historia Fucorum" (1786), the first book published in Russia on marine biology where he described 20 types of algae in the Russian seas, and "Reisen durch Russland zur Untersuchung der drei Naturreiche" (Travels through Russia to Investigate the Three Natural Realms) (between 1770-1774) (Gmelin, 1770-1774).

In 1770, he embarked on a journey on behalf of the Russian Academy of Sciences and in the service of Catherine the Great. The interesting fact is that he was accompanied not only by the other 8-9 professionals, soldiers, but also the flutist and drummer (Darwin Museum, 2021). He researched flora and fauna of the western part of the Caspian Sea. He was also visiting the east coast (present day Kazakhstan), making interesting ethnographic observations there.

The tragic event took place on February 5, 1774 in Dagestan, when Gmelin was taken as a prisoner by the Kaitag Khan, and all attempts by the Russian authorities to influence the khan on the extradition of a scientist were not successful. Catherine II wanted to release the scientist by force, but the Pugachev uprising prevented this step. Gmelin died in captivity in July 1774 from anxiety, unrest, malnutrition, exhaustion and dysentery, and he was only thirty years old (Gokhnadel 2017).

Research of Samuel Gmelin covers the broad spectre - from the Caspian birds, fish as well as mammoth remains described by him in 1769 with a flora and fauna of the Caspian Sea's region (Chernykh, 2015). That is why his books could be inspiration for many scientists of different disciplines - from botanics up to the biology of marine life. The STEAM (Science, Technology, Engineering, Arts, and Mathematics) approach with the power of the art can re-create the life of scientists with their innovations and resides in its ability to represent nature. In the ancient Greece people believed the creativity artists possessed came to them from a muse, a personification of knowledge and the arts that inspired them to write, sculpt, or compose (OECR 2019).

\section{Methodology with STEAM approach}

The method which is demonstrated here is entitled SMS (Stories based on Music about Scientists). It was first introduced in 2013 in the Russian Center of Science and Culture in Ljubljana by the author (under the name of Aleona Sultanova) with the song written about a Russian and Soviet rocket scientist who pioneered astronautic theory - Konstantin Tsiolkovsky. Methodology is based on the experimental design of author's Poetry, Music as well as Visual Arts (video with pictures or compiled documentaries when is placed in video presentation during the performance) incorporating the elements of aesthetics, creativity, and a research discourse about scientists' discoveries from the Age of Enlightenment (17th-18th century) up to the present days.

SMS method is well-incorporated in STEAM (STEM + Art) approach under Art (Music and poem) with "complex problem solving, creativity, critical thinking, people management and cognitive flexibility" (OECR 2019). In addition, the incorporation of elements like SMS related to poem and music provides STE(A)M with real opportunities for innovation in teaching, training as a new learning method. Thus, 
STEAM SMS method is based on research delivered in the form of song - with a poem where its context can be enriched through the means of music. The example is published in the 2nd Proceedings of International Symposium Socratic Lectures 2019 about Baron Valvazor, a natural historian and polymath from Carniola (present-day Slovenia), and the story (poem) about him with the music score (Sultanova, 2019). The song "Baron Valvazor" was also performed by Duo "Al-Chemy" during Symposium in 2019 with some accompanying pictures. This story about life of Gmelin is based on research and became the source of inspiration to create a song. Here we publish the poem in Russian with its translation in English.

\section{Methodology with STEAM approach}

SMS method - stories based on music about scientists is presented here through the song entitled "Дорога длиной на всю жизнь" (The road of a lifetime) and dedicated to Samuel (George) Gottlieb Gmelin, the scientist of the 18th century. The original is in Russian language, and translation in English is also provided. The music scores are not attached here (due to the lengths) but can be performed. Both lyrics and music are written by Aleona Sultanova, and this pseudonym used by the author of this article for her compositions and poems.

\section{Дорога длиной на всю жизнь Посвящено Гмелин, Самуид Готдиб (1744-1774).}

Восемнадцатый век. Тюбинген... Ты отсюда отправишься в путь,

И дорога длиной на всю жизнь, твой красивый недолгий путь

Чтоб узнать величие морей, и как водоросли растут,

Ты в Голландию путь держал, чтоб в России себя воплотить

\section{Припев}

Вода-Вода, горы-берега, степь бескрайних равнин и пустынных долин

Вода-Вода, «трёх царств естества», дикой лошади след в «царские луга»

Кистяной колокольчик в пуху на лугах у Валдайских гор

Ты открыл здесь свою главу из растений, птиц, рыб и цветов

И на западе Каспия, где ты проложишь чудесный след

Барабанщик твой дух пробудит, а флейтист на птиц чары пустит

\section{Припев}

Вода-Вода, горы-берега, степь бескрайних равнин и пустынных додин

Вода-Вода, «трёх царств естества», дикой лошади

The road of a lifetime dedicated to Gmelin, Samuel Gotlieb (1744-1774) (translation)

Eighteenth century. Tübingen...You will start your journey from here,

And this road is a lifetime, your beautiful short journey

To know the majesty of seas, and how algae will grow,

You made your way to Holland in order to realise yourself in Russia

Chorus

Water-Water, Mountains-Shores, steppe of endless plains and desert valleys

Water-Water, "of three kingdoms of nature", a wild horse trail in the "royal meadows"

Flower bell in fluff in the meadows near the Valdai Mountains

You opened your chapter here from plants, flowers and birds

And in the west of the Caspian Sea, where you will lay a wonderful trail

Your drummer will awake your spirit and flutist will cast spells on birds

\section{Chorus}

Water-Water, Mountains-Shores, steppe of endless plains and desert valleys

Water-Water, "of the three kingdoms of nature", a wild horse trail in the "royal meadows" 
The song refers to the concepts and names used in the original books of Gmelin. SMS method might rise different questions, and requires some small initial discussion what was so stimulating to write about it. For instance, the "white horse" used to be named "tarpan", a Kazakh or Kyrgyz name meaning "wild horse" which is derived from a Turkic language - The horse was named after Gmelin, but it disappeared or almost disappeared by the end of 18 th century.

\section{Conclusions}

SMS method has a motivational focus to stimulate interests to learn, understand and innovate as well as ask questions. It is well suited under umbrella of STEAM, where art is presented by music and poem, and brings their power of influence (Sachant and Tekippe, 2022). So far it has not been discovered in any publications related to songs about scientists and their innovations. Therefore, it can potentially bring the new research and innovations. The discoveries and innovations are very often coming from the inspiration of stories from the life of such scientists of the Past as Samuel Gmelin.

Conflicts of Interest: The author declares no conflict of interest.

\section{References:}

1. Chernykh E. (Елена Черных) 2015, июль. Как ученый Гмелин исследовал под Воронежем «скелеты слонов» https://infovoronezh.ru/News/Kak-uchenyiy-Gmelin-issledoval-pod-Voronejem-skeletyi-slonov-39539.html

2. Darwin Museum (2021), Дарвиновский музей. Видеорепортаж из фондов музея «Трагическая история научной экспедиции второй половины XVIII века на юг России» Available at:

http://www.darwinmuseum.ru/projects/event/den-istoricheskogo-i-kul-turnogo-naslediya-moskvy

3. Gmelin, Samuel Gottlieb (1743-1774) Global plants. Available at: https://plants.jstor.org/stable/10.5555/al.ap.person.bm000374049

4. Gokhnadel V.Виктор Гохнадель (2017, март). Талантливый и дерзкий путешественник . Available at: https://daz.asia/ru/talantlivyj-i-derzkij-puteshestvennik/

5. OECR (Opinion of the of the European Committee of the Regions - Strengthening STE(A)M education in the EU (2019/C 404/06)

6. $\quad$ Sachant PJ, Tekippe R. Art and Power. Available at: https://alg.manifoldapp.org/read/introduction-to-art-design-context-and-meaning/section/54129c96-ca5a-4108-832b-9e $3180 \mathrm{e} 85 \mathrm{cc} 8$

7. Silva PC, Basson P, Moe RL. Catalogue of the benthic marine algae of the Indian Ocean .Univ of California Press. 1996.

8. Sultanova A. Baron Valvazor. International Symposium Socratic Lectures 2019,110-112 . Available at: https://repozitorij.uni-lj.si/IzpisGradiva.php?id=113109 